Anjarsari, I.R.D. · S. Rosniawaty · C. Suherman

\title{
Rekayasa ekofisiologis tanaman teh belum menghasilkan klon GMB 7 melalui pemberian asam humat dan pupuk hayati konsorsium
}

\section{Ecophysiology engineering of tea plant of GMB 7 clone by humic acid and consorsium biofertilizer}

Diterima : Januari 2015/Disetujui : Februari 2015/Dipublikasikan : Maret 2015

CDepartment of Crop Science, Padjadjaran University

\begin{abstract}
Tea is the one of important commo-dities in Indonesia. Ecological engineering to increase the productivity generally is done by fertilization. Accordingthe principle of sustain-able agriculture is now the estate are using eco-friendly inputs, such as like using humic acid and consortium biofertilizers (CB). Currently humic acid has been used as a fertilizer complement which can improve the utilization of fertilizers and enhanced plant growth . In addition to humic acid, one of the alternatives to improve the growth of tea plants are not produced by giving biofertilizer consortium of phosphate solubilizing bacteria, nitrogen-fixing bacteria and potassium solubilizing bacteria. The purpose of research is to determined the effect of humic acid and biofertilizers consortium can optimize immature tea plant nutrients in order to improve the efficiency of fertilization. The experimental design was using randomized block design (RBD) with the control treatment, $10 \mathrm{~mL}$ of humic acid, $20 \mathrm{~mL}$ of humic acid $30 \mathrm{~mL}$ Humic acid, $1.0 \mathrm{~g}$ of/plant, $2.0 \mathrm{~g} /$ plant and a combination of both that there are nine treatment were repeated three times. The experimental results showed that there was effect of humic acid and consortium biofertilizers on the growth of tea immature plant of GMB 7 clone and the combination of $1.0 \mathrm{~g}$ of biofertilizer/plant $+10 \mathrm{ml}$ of Humic Acid/plant showed the higher nett asimilation rate, leaf width and area index than other treatments.
\end{abstract}

Keywords : Tea $\cdot$ Humic acid $\cdot$ Consortium biofertilizers

\footnotetext{
Dikomunikasikan oleh Yudithia Maxiselly

Anjarsari I.R.D. ${ }^{1} \cdot$ S. Rosniawaty ${ }^{1}$ ' C. Suherman ${ }^{1}$

1 Program Studi Agroteknologi Jurusan Budidaya

Pertanian Fakultas Pertanian Universitas Padjadjaran

Jl.Raya Bandung Sumedang Km.21 Jatinangor

Korespondensi: intan_rdewi@yahoo.co.id
}

Sari Teh merupakan komoditas perkebunan penting di Indonesia. Rekayasa ekologis yang dilakukan untuk meningkatkan produktivitas tanaman teh di perkebunan adalah melalui tindakan pemupukan. Sejalan dengan prinsip pertanian berkelanjutan kini pihak pekebun pada umumnya menggunakan input yang lebih ramah lingkungan, diantaranya dengan menggunakan asam humat dan pupuk hayati konsorsium. Saat ini asam humat telah dimanfaatkan sebagai pelengkap pupuk yang dapat meningkatkan pemanfaatan pupuk dan meningkatkan pertumbuhan tanaman. Selain asam humat, salah satu alternatif untuk meningkatkan pertumbuhan tanaman teh belum menghasilkan adalah dengan pemeberian pupuk hayati konsorsium yang terdiri dari bakteri pelarutf posfat, bakteri penambat nitrogen dan bakteri pelarut kalium.

Tujuan penelitian adalah untuk mengetahui sampai sejauh mana pemberian asam humat dan pupuk hayati konsorsium dapat mengoptimalkan nutrisi tanaman teh belum menghasilkan guna meningkatkan efisiensi pemupukan pada teh di fase TBM. Penelitian ini dimenggunakan rancangan acak kelompok (RAK) dengan perlakuan yakni kontrol, 10 mLasam humat, $20 \mathrm{~mL}$ asam humat, $30 \mathrm{~mL}$ Asam Humat, 1,0 g PHK/tanaman, 2,0 g PHK/tanaman dan kombinasi keduanya sehingga terdapat sembilan perlakuan yang diulang 3 kali. Hasil percobaan menunjukkan bahwa Terdapat pengaruh pemberian asam humat dan pupuk hayati konsorsium terhadap pertumbuhan tanaman teh belum menghasilkan klon GMB 7 serta pada kombinasi 1,0 g PHK/ tanaman + $10 \mathrm{~mL}$ Asam humat menunjukkan kecenderungan nilai laju asimilasi bersih, luas daun, nisbah luas daun yang lebih tinggi dibandingkan perlakuan lainnya.

Kata kunci : Teh - Asam humat - Pupuk hayati konsorsium 


\section{Pendahuluan}

Pada umumnya tindakan budidaya yang dilakukan untuk meningkatkan produktivitas tanaman teh di perkebunan adalah melalui tindakan pemupukan. Sejalan dengan prinsip pertanian berkelanjutan kini pihak pekebun pada umumnya menggunakan input yang lebih ramah lingkungan, diantaranya dengan menggunakan asam humat dan pupuk hayati konsorsium. Penggunaan pupuk anorganik pada tanah tidak semuanya terserap secara optimal oleh tanaman karena unsur hara tersebut mengalami pencucian, penguapan, atau terikat oleh tanah. Hal ini menyebabkan rendahnya efisiensi pemupukan, berpotensi menyebabkan pencemaran lingkungan, dan akumulasi residu pupuk dapat mengakibatkan menurunnya kualitas tanah baik fisik, kimia maupun biologinya. Penggunaan pupuk organik atau suplemen hara lain seperti asam humat (humic acid) saat ini banyak dilakukan, selain didasarkan alasan keamanan produk juga dapat memperbaiki kesuburan tanah.

Saat ini asam humat telah dimanfaatkan sebagai pelengkap pupuk yang dapat meningkatkan pemanfaatan pupuk dan meningkatkan pertumbuhan tanaman. Turan et al. (2011) melaporkan bahwa asam humat sebagai pelengkap pupuk dapat meningkatkan pertumbuhan tanaman jagung pada tanah dengan kadar garam tinggi (soil-salinity condition). Chen dan Aviad (1990), Varanini dan Pinton (1995) juga telah meneliti efek positif humat pada perkecambahan benih, pertumbuhan semai bibit, inisiasi dan pertumbuhan akar, perkembangan tunas dan pengambilan nutrisi makro dan mikro tanaman. Humat sebagi komponen utama bahan organik tanah mempunyai efek langsung dan tidak langsung pada pertumbuhan tanaman, meliputi peningkatan sifat-sifat tanah seperti aggregasi, aerasi, permeabilitas, kapasitas menahan air, transport dan ketersediaan mikronutrien (Tan K.H., 2003).

Pupuk hayati konsorsium merupakan pupuk hayati yang terdiri dari beberapa jenis mikroba yang membantu meningkatkan ketersediaan hara tanah seperti menambat nitrogen (N) oleh bakteri penambat $\mathrm{N}$ non simbiotik, melarutkan fosfat $(\mathrm{P})$ oleh bakteri pelarut fosfat (P) dan menghasilkan fitohormon. Rekomendasi dosis pupuk hayati konsorsium nuntuk tanaman perkebunan adalah 1000-2000 g/ha tanaman menghasilkan. Jenis bakteri Azotobacter sp. non simbiotik dikenal mampu memfiksasi $\mathrm{N}$ bebas di udara sehingga langsung dapat dimanfaatkan oleh tanaman. Dengan demikian, maka pemanfaatan bakteri pelarut fosfat dan bakteri penambat nitrogen secara konsorsium diharapkan dapat meningkatkan suplai unsur hara $\mathrm{N}$ dan $\mathrm{P}$ bagi tanaman, sedangkan untuk pemenuhan unsur hara makro kalium (K) akan diperoleh tanaman dari pupuk dasar.

Tujuan penelitian adalah untuk mengetahui sampai sejauh mana pemberian asam humat dan pupuk hayati konsorsium dapat mengoptimalkan nutrisi tanaman teh belum menghasilkan guna meningkatkan efisiensi pemupukan pada teh di fase TBM.

\section{Bahan dan Metode}

Percobaan dilaksanakan di Kebun Percobaan Ciparanje Fakultas Pertanian Universitas Padjadjaran Pelaksanaan dimulai bulan Juni 2014 sampai dengan Oktober 2014. Kebun percobaan mempunyai ketinggian tempat 700 meter di atas ermukaan laut, jenis tanah ordo Inceptisol dengan tipe iklim berdasarkan curah hujan termasuk tipe C (Schmidt dan Ferguson,1951).

Bahan tanaman yang akan digunakan pada penelitian ini tanaman teh belum menghasilkan (TBM) klon GMB 7 sejumlah 135 tanaman dengan jarak tanam 110 × $90 \mathrm{~cm}$. Pupuk Urea (N), $\mathrm{KCl}\left(\mathrm{K}_{2} \mathrm{O}\right)$, SP-36 $\left(\mathrm{P}_{2} \mathrm{O}_{5}\right)$, Kiserit $(\mathrm{MgO})$, dan pupuk hayati konsorsium diperoleh dari PT Artha Ully, asam humat dari Balai Penlitian Kehutanan Cimanggu Bogor.

Rancangan percobaan yang digunakan adalah Rancangan Acak Kelompok (RAK) pola sederhana dengan 9 perlakuan dan diulang tiga kali untuk setiap perlakuan. Terdapat 27 satuan percobaan. Setiap satuan percobaan terdiri dari 5 tanaman. Jumlah seluruh tanaman 135 tanaman.

Perlakuan yang diberikan sebagai berikut:
A : Tanpa pupuk hayati konsorsium (PHK) dan asam humat
B : $2 \mathrm{~g}$ PHK/Tanaman
C : $30 \mathrm{~mL}$ As Humat
D : $30 \mathrm{~mL}$ Asam Humat $+1,0 \mathrm{~g} \mathrm{PHK} / \tan$
E : $20 \mathrm{~mL}$ Asam Humat + 1,0 g PHK/tan
F : $10 \mathrm{~mL}$ Asam Humat + 1,0 g PHK/tan
$\mathrm{G}: 30 \mathrm{~mL}$ Asam Humat + 2,0 g PHK/tan
$\mathrm{H}: 20 \mathrm{~mL}$ asam humat $+1,0 \mathrm{~g} \mathrm{PHK} / \tan$
I : $10 \mathrm{~mL}$ asam humat $+1,0 \mathrm{~g} \mathrm{PHK} / \mathrm{tan}$ 
Untuk mengetahui respon perlakuan antara asam humat dengan PHK dilakukan pengamatan terhadap variabel respon meliputi laju pertumbuhan tanaman rata-rata (LPT), laju asimilasi bersih rata-rata (LAB), nisbah luas daun (NLD), jumlah klorofil daun. Untuk data penunjang, dilakukan analisis tanah sebelum dan sesudah percobaan, hama penyakit, gulma dan data curah hujan selama percobaan. Pengamatan untuk komponen dilakukan setiap 1 minggu sekali dan datanya digabung per satu bulan sekali. Analisis statistik menggunakan nilai means

Meliputi penyiapan media tanam berisi tanah inceptisol jatinangor dimasukkan ke dalam polibeg ukuran $55 \times 22 \mathrm{~cm}$ yang telah dianalisis dulu sebelumnya. Pemberian campuran PHK dan asam humat hanya dilakukan satu kali, yaitu diawal penelitian. PHK yang berbentuk serbuk dicampur terlebih dahulu dengan kompos halus sesuai perlakuan. Campuran diberikan di sekitar tanaman lalu ditutup untuk menghindari hilangnya PHK akibat percikan air hujan. Pemberian asam humat diberikan sekali di awal kepada tanaman dengan cara menyemprotkan ke tanah. Pemeliharaan dilakukan pada pertanaman teh dari gulma, hama dan penyakit selama percobaan.

\section{Hasil dan Pembahasan}

\section{Pengamatan Penunjang}

Analisis Tanah, Hama Penyakit dan Gulma. Hasil analisis tanah Inceptisol Jatinangor menunjukkan bahwa tanah bereaksi masam dengan $\mathrm{pH} 4,86$. Hal ini menunjukkan bahwa keadaan tersebut sesuai dengan persyaratan yang dibutuhkan untuk pertanaman teh, yaitu pada kisaran 4,5 - 6,0. Kandungan Corganik rendah $(1,40 \%)$ dan kandungan $\mathrm{N}$-total termasuk sedang $(0,29)$ dengan rasio $C$ terhadap $\mathrm{N}(\mathrm{C} / \mathrm{N})$ 4,83 (sangat rendah). Rasio C terhadap $\mathrm{N}$ yang sangat rendah rendah menunjukkan bahwa tanah memiliki unsur hara yang cukup dan siap digunakan oleh tanaman karena proses pendekomposisian bahan di dalam tanah telah terjadi (Asosiasi Penelitian dan Pengembangan Perkebunan Indonesia, 2002). Kandungan $\mathrm{P}_{2} \mathrm{O}_{5}$ total yang tinggi $52,50 \mathrm{mg} / 100 \mathrm{~g}$ sedangan $\mathrm{P}_{2} \mathrm{O}_{5}$ tersedia yang sangat rendah $(1,89)$ menunjukkan bahwa tanah yang digunakan sebagai media memiliki beberapa sifat kimia yang kurang baik.
Perbaikan sifat kimia ini dapat diperbaiki dengan pemberian pupuk hayati dan pupuk organik.

Hasil pengamatan di lapangan menunjukkan bahwa serangan hama lebih dominan pada bulan pertama, tetapi serangan penyakit selama percobaan tidak dijumpai. Terdapat hama yang menyerang tanaman teh, diantaranya belalang (Valanga nigricornis). Hama ini menyerang tanaman khususnya bagian daun dengan ditandai adanya bekas gigitan pada pinggiran daun. Pada bulan pertama percobaan intensitas serangan hama ringan dan tidak menimbulkan kerusakan yang berarti sehingga pengendaliannya hanya dilakukan dengan cara mekanis tanpa pengendalian secara kimia. Memasuki bulan kedua dan ketiga intensitas serangan belalang cukup tinggi ditandai dengan banyaknyya populasi teh yang dimakan daunnya. Sebagai langkah akhir digunakan insektisida berbahan aktif insektisida berbahan aktif Abamectin 18 g.L-1 . Insektisida bersifat kontak berwarna coklat kehitaman berbentuk pekatan yang diemulsikan untuk mengendalikan hama pada tanaman teh 0,5 - $1 \mathrm{~mL} \cdot \mathrm{L}^{-1}$ air.

Gulma yang tumbuh selama percobaan berlangsung antara lain teki (Cyperus rotundus), babadotan (Ageratum conyzoides), lampuyangan (Panicum repens) dan alang-alang (Imperata cylindrica). Pengendalian gulma dilakukan secara manual pada bulan pertama sampai dengan akhir percobaan.

Analisis Asam Humat. Hasil analisis asam humat di Balai Penelitian Tanah Bogor menunjukkan bahwa $\mathrm{pH} \mathrm{H}_{2} \mathrm{O}$ sebesar 10,1 (basa), C organik $4 \%$, asam humat $6,16 \%$, kandungan $\mathrm{N}$ total $0,16 \%\left(\mathrm{NH}_{4} 0,11 \%, \mathrm{NO}_{3} 0,04 \%\right)$. Parameter $\mathrm{C} / \mathrm{N}$ rasio asam humat ini sebesar 25 , hal ini sudah sesuai dengan standar persyaratan teknis minimal bahan pembenah organik 25-35.

\section{Pengamatan Utama}

Laju Pertumbuhan Tanaman (LPT). Laju pertumbuhan tanaman (LPT) merupakan penimbunan berat kering per satuan waktu. Laju pertumbuhan tanaman (LPT) pada bulan ke-1 dapat dilihat pada Tabel 1.

Diduga kombinasi asam humat dan pupuk hayati konsorsium dapat meningkatkan laju pertumbuhan tanaman teh 1 BST sampai dengan 3 BST. Asam humat adalah ekstrak bahan organik yang secara tidak langsung dapat mempengaruhi pertumbuhan tanaman dengan meningkatkan kesuburan tanah melalui perbai- 
kan kondisi tanah sehingga pertumbuhan tanaman menjadibaik. Oleh karena itu pemberian asam humat dapat memacu pertumbuhan tinggitanaman. Menurut Tan (2003), pemberian asam humat dapat menjaga ketersedianhara makro dan mikro di dalam tanah menjadi lebih banyak sehingga lebih mudah diserap akar tanaman. Selain itu asam humat juga dapat memperbaiki kesuburan tanah dengan memacu pertumbuhan mikroorganisme tanah dan meningkatkan kapasitas tukar kation (KTK) hara di dalam tanah.

Tabel 1. Pengaruh Pemberian Asam Humat dan Pupuk Hayati Konsorsium terhadap Laju Pertumbuhan Tanaman (LPT) 1-3 BSP (g m-2 bulan-1)

\begin{tabular}{crrr}
\hline \multirow{2}{*}{ Perlakuan } & \multicolumn{3}{c}{$\begin{array}{c}\text { Laju Pertumbuhan Tanaman } \\
\text { (LPT) }\left(\mathbf{g ~ m}^{-2} \text { bulan }^{-1}\right)\end{array}$} \\
\cline { 2 - 4 } & \multicolumn{1}{c}{$\mathbf{1}$} & \multicolumn{1}{c}{$\mathbf{3}$} \\
\hline A & 4,39 & 8,88 & 15,51 \\
B & 0,49 & 64,88 & 24,39 \\
C & 25,85 & 48,73 & 6,29 \\
D & 11,71 & 8,44 & 43,76 \\
E & 42,44 & 13,76 & 38,44 \\
F & 24,88 & 59,46 & 0,93 \\
G & 15,12 & 50,73 & 2,44 \\
H & 7,32 & 64,15 & 0,73 \\
I & 24,88 & 42,83 & 13,76 \\
\hline \hline
\end{tabular}

Dari Tabel 1 di atas terlihat bahwa nilai LPT mengalami kecenderungan peningkatan terjadi pada bulan kedua setelah perlakuan kemudian menurun kembali di bulan ketiga. Seperti terlihat pada Gambar 1.

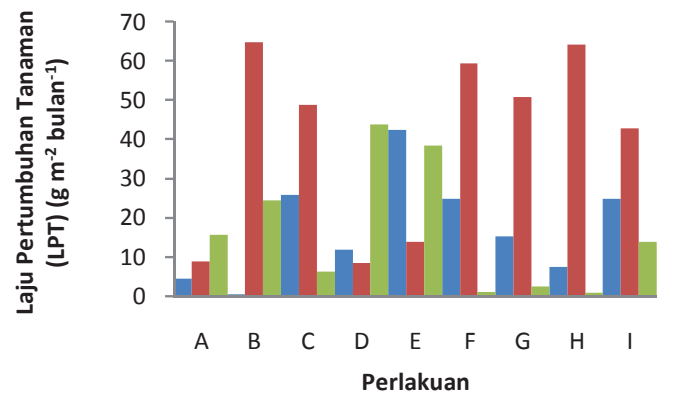

Gambar 1. Laju Pertumbuhan Tanaman (LPT) $\left(\mathrm{g} \mathrm{m}^{-2}\right.$

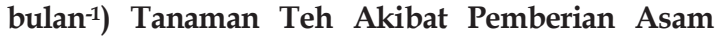
Humat dan Pupuk Hayati Konsorsium pada Bulan 1, 2 dan 3 Bulan Setelah Perlakuan (BSP).

Laju Asimilasi Bersih (LAB). Laju asimilasi bersih (LAB) mengekspresikan efisiensi fotosintesis daun dalam suatu tanaman (Gardner dkk., 1991). Laju asimilasi bersih (LAB) pada bulan ke-1 dapat dilihat pada Tabel 2 .

Tabel 2. Pengaruh Pemberian Asam Humat dan Pupuk Hayati Konsorsium terhadap Laju Asimilasi Bersih (LAB) $\left(\mathrm{g} \mathrm{m}^{-2}\right.$ bulan $\left.^{-1}\right)$

\begin{tabular}{cccc}
\hline \hline \multirow{2}{*}{ Perlakuan } & \multicolumn{3}{c}{$\begin{array}{c}\text { Laju Asimilasi Bersih (LAB) } \\
\left(\mathbf{g ~ m}^{-2} \text { bulan }^{-1}\right)\end{array}$} \\
\cline { 2 - 4 } & $\mathbf{1}$ & $\mathbf{2}$ & $\mathbf{3}$ \\
\hline A & 0,019 & 0,036 & 0,044 \\
B & 0,003 & 0,562 & 0,099 \\
C & 0,105 & 0,339 & 0,020 \\
D & 0,039 & 0,027 & 0,113 \\
E & 0,177 & 0,081 & 0,091 \\
F & 0,155 & 2,009 & 0,003 \\
G & 0,078 & 0,420 & 0,007 \\
H & 0,038 & 0,602 & 0,003 \\
I & 0,079 & 0,177 & 0,036 \\
\hline \hline
\end{tabular}

Berdasarkan data perkembangan LAB menunjukkan bahwa pemberian pupuk hayati konsorsium dan asam humat belum menunjukkan pengaruh yang nyata. Pada dasarnya, adanya senyawa humat dalam tanah yang bersifat bioregulator agent dan memiliki kapasitas penukar ion tinggi dapat menginduksi terjadinya disintegrasi bertahap dari mineral silikat dan aluminosilikat). Akibatnya pelarutan makro dan mikro nutrisi tanaman, dan garamgaram lain yang kelarutannya cukup rendah sehingga unsur-unsur hara tersebut berubah menjadi bentuk tersedia yang mudah diserap tanaman. Selain itu senyawa humat sendiri merupakan sumber utama makro dan mikro nutrisi tanaman diatas dan unsur yang paling dibutuhkan bagi tanaman seperti nitrogen (Winner, 1985)

Ada kecenderungan nilai LAB kian menurun, laju asimilasi bersih tidak konstan terhadap waktu, tetapi mengalami penurunan dengan bertambahnya umur tanaman (Gardner et al., 1991). Nilai LAB tertinggi pada saat tajuk tanaman teh belum menutup, hal ini dapat dilihat pada bulan pertama, kemudian menurut hingga bulan ketiga pada sebagian besar perdu, karena sebagian besar daunnya tidak terkena sinar matahari langsung seperti terlihat pada Gambar 2.

Semakin tumbuhnya tanaman dan dengan meningkatnya indeks luas daun, maka semakin banyak daun yang terlindung, yang menye- 
babkan penurunan laju asimilasi bersih. Menurut Gardner et al. (1991), laju asimilasi bersih merupakan ukuran efisiensi daun menghasilkan bahan kering dan secara langsung dipengaruhi oleh kemampuan daun dalam menyerap radiasi matahari dan hara. Selanjutnya Gardner menyatakan bahwa luas daun mempunyai kaitan yang erat dengan laju asimilasi bersih. Daun yang semakin luas akan menurunkan laju asimilasi bersih karena antara daun satu dengan daun lainnya saling menaungi. Hal tersebut berakibat daun-daun di bagian bawah tidak bisa melakukan fotosintesis secara maksimal. Kondisi tersebut dapat menyebabkan luas daun yang berbeda nyata belum tentu mempengaruhi laju asimilasi bersih.

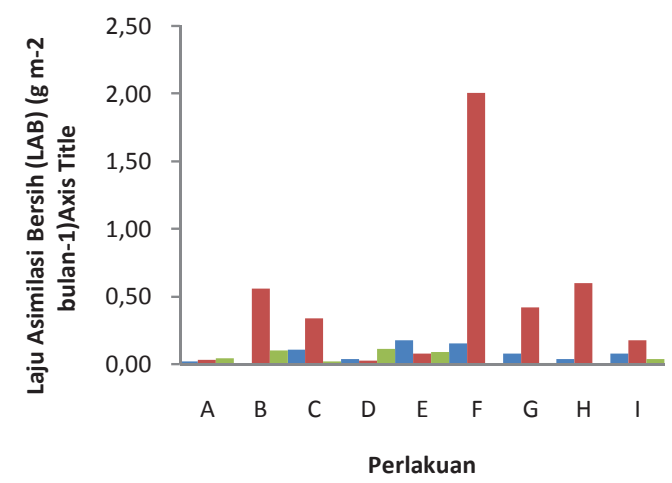

Gambar 2. Laju Asimilasi Bersih (LAB) $\left(\mathrm{g} \mathrm{m}^{-2}\right.$

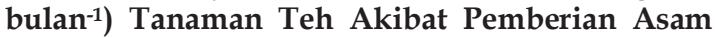
Humat dan Pupuk Hayati Konsorsium pada Bulan 1, 2 dan 3 BSP.

Luas Daun (LD). Luas daun juga berhubungan erat dengan kemampuan tanaman menerima cahaya/radiasi matahari yang sangat dibutuhkan dalam proses fotosintesis untuk menghasilkan karboohidrat yang akan digunakan sebagai sumber energi bagi pertumbuhan tanaman. Kemampuan daun untuk menghasilkan fotosintat dapat dilihat dari produktivitas persatuan luas daun.

Dari Tabel 3 terlihat bahwa luas daun semakin meningkat dengan semakin bertambahnya umur tanaman. Kemampuan daun untuk menghasilkan produk fotosintat ditentukan oleh produktivitas per satuan luas daun dan total luas daun (Fahn, 1992). Pada Gambar 3 berikut ini terlihat bahwa ada kecenderungan peningkatan luas daun pada bulan ketiga setelah perlakuan.
Tabel 3. Pengaruh Pemberian Asam Humat dan Pupuk Hayati Konsorsium terhadap Luas Daun (LD) $\left(\mathrm{cm}^{2}\right)$ 1-3 BSP.

\begin{tabular}{cccc}
\hline \hline \multirow{2}{*}{ Perlakuan } & \multicolumn{3}{c}{ Luas Daun (LD) $\left(\mathbf{c m}^{\mathbf{2}}\right)$} \\
\cline { 2 - 4 } & $\mathbf{1}$ & $\mathbf{2}$ & $\mathbf{3}$ \\
\hline A & 250,40 & 510,80 & 664,01 \\
B & 261,67 & 473,09 & 648,93 \\
C & 209,05 & 493,73 & 736,85 \\
D & 258,65 & 620,96 & 732,71 \\
E & 188,60 & 464,84 & 828,97 \\
F & 254,87 & 422,85 & 850,88 \\
G & 290,55 & 502,40 & 817,70 \\
H & 259,87 & 473,09 & 692,24 \\
I & 263,37 & 648,93 & 858,08 \\
\hline \hline
\end{tabular}

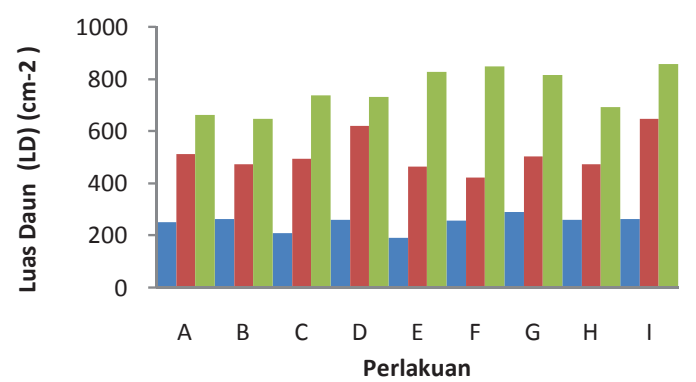

Gambar 3. Luas Daun (LD) $\left(\mathrm{cm}^{2}\right)$ tanaman teh akibat pemberian asam humat dan pupuk hayati konsorsium pada bulan 1, 2 dan 3 BSP.

Pemberian PHK dan asam humat diduga dapat meningkatkan ketersediaan hara yang dibutuhkan tanaman teutama hara yang dibutuhkan untuk perkembangan daun, yaitu $\mathrm{N}$ dan Mg. Peningkatan total luas daun erat kaitannya dengan unsur hara terutama unsur $\mathrm{N}, \mathrm{P}$, dan $\mathrm{Mg}$. Sesuai dengan pendapat Lakitan (2001), bahwa unsur $\mathrm{N}$ sangat mempengaruhi pertumbuhan dan perkembangan daun. Konsentrasi nitrogen tinggi umumnya menghasilkan total luas daun yang lebih besar. Sutejo (2002) juga menyatakan bahwa nitrogen merupakan unsur utama dalam pertumbuhan tanaman untuk pembentukan bagian vegetatif tanaman seperti daun, sedangkan fosfor berfungsi sebagai penyusun protein dan magnesium sebagai penyusun molekul klorofil berperan dalam proses fotosintesis sehingga fotosintat yang dihasilkan dapat ditranslokasikan untuk mendukung pertambahan pertumbuhan daun.

Peran asam humat yang lain dalam tanah membantu penataan liat dan pembenahan tanah, memegang dan mentransfer unsur mikro dari tanah ke tanaman, meningkatkan daya pegang air, dan merangsang perkembangan populasi mikroflora dalam tanah. 
Luas daun tanaman ditentukan pertama tama oleh jumlah karbohidrat yang dialokasikan ke dbagian daun, sehingga pembagian karbohidrat ke daun sangat menentukan perkembangan tanaman. Menurut Goldsworthy dan Fisher (1992) bahwa faktor yang mempengaruhi besarnya indeks luas daun adalah kerapatan tanam dan penyediaan hara nitrogen.

Nisbah Luas Daun (NLD). Nisbah luas daun merupakan nisbah antara luas daun dengan berat kering daun. Nisbah luas daun mencakup pembagian dan translokasi fotosintat ke tempat sintesa bahan daun dan efisiensi penggunaan substrat dalam pembentukan luas daun (Sitompul dan Guritno, 1995).

Tabel 4. Pengaruh Pemberian Asam Humat dan Pupuk Hayati Konsorsium terhadap Nisbah Luas Daun (NLD) $\left(\mathrm{m}^{-2} \mathrm{~g}^{-1}\right)$ 1-3 BSP.

\begin{tabular}{cccc}
\hline \hline \multirow{2}{*}{ Perlakuan } & \multicolumn{3}{c}{ Nisbah Luas Daun (NLD) $\left.\mathbf{( m}^{-\mathbf{2}} \mathbf{g}^{-1}\right)$} \\
\cline { 2 - 4 } & $\mathbf{1}$ & $\mathbf{2}$ & $\mathbf{3}$ \\
\hline A & 16,69 & 19,28 & 25,06 \\
B & 16,99 & 13,44 & 18,44 \\
C & 17,00 & 12,56 & 18,75 \\
D & 17,13 & 17,59 & 20,76 \\
E & 16,99 & 13,92 & 24,82 \\
F & 16,99 & 14,89 & 29,96 \\
G & 16,99 & 14,86 & 24,19 \\
H & 17,32 & 14,16 & 20,73 \\
I & 16,99 & 19,14 & 25,31 \\
\hline \hline
\end{tabular}

Keterangan : Nilai Rata-rata perlakuan yang tidak ditandai huruf yang pada kolom yang sama menunjukkan tidak berbeda nyata menurut uji $\mathrm{F}$

Pada Gambar 4 berikut ini terlihat bahwa ada kecenderungan nisbah luas daun pada bulan pertama hingga bulan ketiga setelah perlakuan. Bila dilihat dari Gambar 4 menunjukkan bahwa perlakuan F (1,0 g PHK / tan + $10 \mathrm{~mL}$ Asam Humat memberikan kecenderungan nisbah luas daun lebih tinggi dibandingkan perlakuan yang lain.

Nilai NLD sangat bergantung pada besarnya luas daun serta bobot kering daun, sedangkan besar kecilnya bobot kering daun akan sangat bergantung pada bobot basah daun. Bobot basah tanaman berkaitan dengan transportasi fotosintat ke daerah pemanfaatan seperti daun dan batang. Jumlah daun mempengaruhi jumlah fotosintat yang dihasilkan. Selain itu, kadar air dalam tanaman sendiri sangat mempengaruhi bobot basah tanaman karena lebih dari $70 \%$ penyusun tanaman adalah air. Akar merupakan penunjang pertumbuhan tajuk tanaman, sehingga potensi pertumbuhan akar harus dicapai optimal untuk mencapai potensi pertumbuhan tajuk yang optimal pula (Sitompul dan Guritno, 1995).

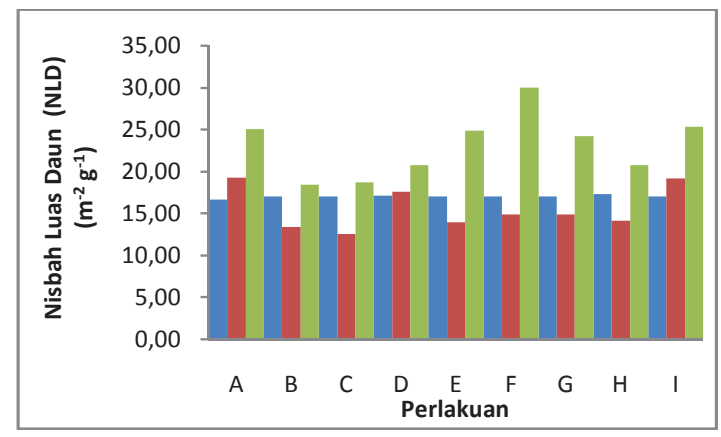

Gambar 4. Nisbah Luas Daun (NLD) $\left(\mathrm{m}^{-2} \mathrm{~g}^{-1}\right)$ Tanaman Teh Akibat Pemberian Asam Humat dan Pupuk Hayati Konsorsium pada Bulan 1, 2 dan 3 BSP.

Kadar Klorofil Daun. Pengukuran karakter fisiologi seperti kandungan klorofil, merupakan salah satu pendekatan untuk mempelajari pengaruh kekurangan air terhadap pertumbuhan dan hasil produksi, karena parameter ini berkaitan erat dengan laju fotosintesis (Li et al., 2006).

Klorofil berperan penting dalam reaksi fotosintesis. Menurut Curtis dan Clark (1950) dikutip Hendriyani dan Setairi (2009), pembentukan klorofil daun bergantung pada berbagai faktor, seperti temperatur, cahaya, unsur nitrogen $(\mathrm{N})$, magnesium $(\mathrm{Mg})$, besi $(\mathrm{Fe})$, mangan $(\mathrm{Mn})$, tembaga $(\mathrm{Cu})$, seng $(\mathrm{Zn})$, Sulfur $(\mathrm{S})$ dan oksigen $\left(\mathrm{O}_{2}\right)$. Pada klorofil, nitrogen merupakan unsur yang digunakan untuk mengikat $\mathrm{Mg}$ pada gugus karbon. Kadar klorofil daun selama percobaan dapat dilihat pada Tabel 5 .

Data kadar klorofil daun selama percobaan menunjukkan tidak berbeda nyata,hal ini dimungkinkan karenapenyerapan unsur hara dari tanah oleh akar berjalan dengan baik, sehingga mempengaruhi ketersediaan unsur $\mathrm{N}$ dan $\mathrm{Mg}$ yang berperan penting dalam sintesis klorofil (Syafi 2008). Kandungan klorofil dapat dipakai sebagai indikator yang terpercaya untuk mengevaluasi ketidakseimbangan metabolisme antara fotosintesis dan hasil produksi pada saat kekurangan air (Li et al.,2006).

Namun bila dilihat dari Gambar 5 di bawah ini ada kecenderungan bahwa kadar klorofil daun semakin meningkat seiiring bertambahnya umur tanaman. 
Tabel 5. Pengaruh Pemberian Asam Humat dan Pupuk Hayati Konsorsium terhadap Kadar Klorofil Daun (cci) 1-3 BSP.

\begin{tabular}{cccc}
\hline \hline \multirow{2}{*}{ Perlakuan } & \multicolumn{3}{c}{ Kadar Klorofil Daun (cci) (BSP) } \\
\cline { 2 - 4 } & $\mathbf{1}$ & $\mathbf{2}$ & $\mathbf{3}$ \\
\hline A & 106,55 & 108,43 & 101,73 \\
B & 99,24 & 123,57 & 132,33 \\
C & 104,13 & 106,57 & 164,13 \\
D & 103,01 & 104,39 & 150,40 \\
E & 97,64 & 103,13 & 162,60 \\
F & 104,17 & 105,59 & 156,47 \\
G & 106,31 & 113,87 & 162,70 \\
H & 106,07 & 101,37 & 162,93 \\
I & 92,80 & 115,47 & 155,33 \\
\hline \hline
\end{tabular}

Keterangan: Nilai Rata-rata perlakuan yang tidak ditandai huruf yang pada kolom yang sama menunjukkan tidak berbeda nyata menurut uji $\mathrm{F}$

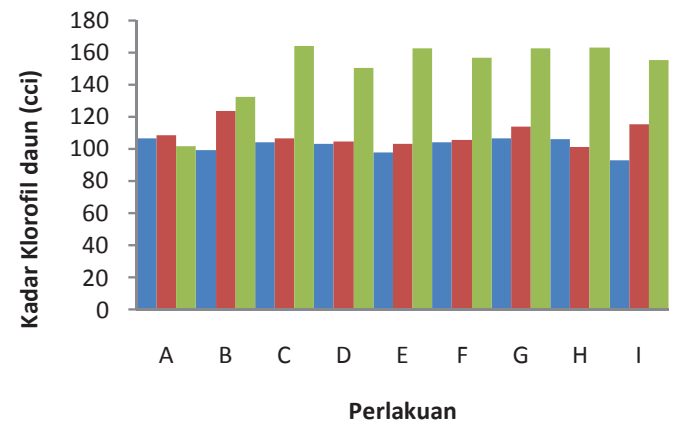

Gambar 5. Kadar Klorofil Daun (cci) Tanaman Teh Akibat Pemberian Asam Humat dan Pupuk Hayati Konsorsium pada Bulan 1, 2 dan 3 BSP.

\section{Kesimpulan dan Saran}

\section{Simpulan}

1. Terdapat pengaruh pemberian asam humat dan pupuk hayati konsorsium terhadap pertumbuhan tanaman teh belum menghasilkan klon GMB 7

2. Pelakuan $10 \mathrm{~mL}$ Asam Humat + 1,0 g $\mathrm{PHK} / \mathrm{tan}$ memberikan kecenderungan nilai laju asimilasi bersih, luas daun, nisbah luas daun yang lebih tinggi dibandingkan perlakuan lainnya

\section{Saran}

Dianjurkan untuk menggunakan asam humat dan pupuk hayati konsorsium untuk meningkatkan pertumbuhan tanaman teh belum menghasilkan.

\section{Daftar Pustaka}

Badan Litbang Pertanian. 2014. Asam Humat, Senyawa Organik Penghemat Pemakaian Pupuk Anorganik.

Chen Y. and Aviad T. 1990. Effect of Humic Substances on Plant Growth. in: MacCarthy P, Clapp CE, Malcolm RL, Bloom PR (Eds.), Humicsubstances in soil and crop sciences: selected reading, Soil Science Society.Am, Madison. p161-187.

Fahn. A. 1992. Anatomi Tumbuhan. PT Gramedia Jakarta

Gardner, F.P., Pearce dan L. Mitchell. 1991. Fisiologi Tanaman Budidaya. Universitas Indonesia Press. h 268-269.

Hendriyani, I. S dan N. Setiari. 2009. Kandungan klorofil dan pertumbuhan kacang panjang (Vigna sinensis) pada tingkat penyediaan air yang berbeda. J. Sains \& Mat. 17(3): 145-150.

Lakitan, B. 2001. Fisiologi Pertumbuhan dan Perkembangan Tanaman. PT. Raja Grafindo Persada. Jakarta. 89 hal.

Li, R., P. Guo, M. Baum, S. Grando, S. Ceccarelli. 2006. Evaluation of chlorophyll content and fluorescence parameters as indicators of drought tolerance in barley. Agricultural Sciences in China 5 (10): 751-757.

Schmidt, F.H. and J.H. Fergusson. 1951. Rainfall Types based on Wet and Dry Period Ratios for Indonesia with Western Nes Guine. Badan Meteorologi dan Geofisika. Jakarta.

Sitompul S.M., dan Bambang Guritno. 1995. Analisis Pertumbuhan Tanaman. Gadjah Mada Univ. Press. Yogyakarta. hal 161-165.

Sutejo, M. M. 2002. Pupuk dan Cara Pemupukan. Reneka Cipta. Jakarta. 177 hal.

Syafi, S. 2008. Respons Morfologis dan Fisiologis Bibit Berbagai Genotipe Jarak Pagar (Jatropha curcas L.) terhadap Cekaman Kekeringan. Tesis. IPB. Bogor.

Tan K.H. 2003. Humic Matter in Soil and Environment, Principles and Controversies. Marcel Dekker.Inc. Madison. New York.

Tan, K. H. 2003. Humic Matter in Soil and the Environment. CRC Press. New York. 408 p.

Varanini Z. and Pinton R. 1995. Humic substances and plant nutrition. Prog Bot 56:97-117. web:http://repository.ipb.ac.id. Diakses 10 Januari 2015

Winner R.W. 1985. Bioaccumulation and toxicity of $\mathrm{Cu}$ as affected by interaction beetwen humic acid and water hardness. Water Res, 19,449-455, 